УДК 35.073.515(338.48+502.35)

JEL: Q26, Q56

KARPENKO O.

PhD. (Economics)

Institute of Market Problems and Economic-Ecological Researches of the

National Academy of Science of Ukraine

Frantsuz'kyj boulevard, 29, Odessa, Ukraine

E-mail:ecolog.ok@ukr.net

KHUMAROVA N.

Dr.Sc. (Economics),

Institute of Market Problems and Economic-Ecological Researches of the

National Academy of Science of Ukraine

Frantsuz'kyj boulevard, 29, Odessa, Ukraine

E-mail:khumarova@nas.gov.ua

\title{
PRIORITIES OF STRATEGIC DEVELOPMENT OF TOURISM ACTIVITIES IN THE COUNTRIES OF THE BLACK SEA REGION
}

The strategic directions of the joint strategy of the countries of the Black Sea basin for creating favorable conditions for the formation and development of a modern competitive recreational and tourism industry that can become the leading sector of sustainable development of the region are justified, and the relevant targets, priorities and tasks are determined. The existing shortcomings that reduce the competitiveness of tourism products and services in the countries of the Black Sea basin are identified.

Keywords: United strategy, the countries of the Black Sea basin, the conditions for the development of a competitive recreation and tourism industry, the goals and objectives of recreational tourism, the ecologization of the tourism sector, innovative potential.

КАРПЕНКО О.О.

кандидат екон. наук, наук. співроб.

Інститут проблем ринку та економіко-екологічних досліджень НАНУ

Франиузький бульвар, 29, м. Одеса, Украӥна, 65044

E-mail:ecolog.ok@ukr.net

ХУМАРОВА H.I.

д-р екон. наук, головн. наук. співроб.

Інститут проблем ринку та економіко-екологічних досліджень НАНУ

Франиузький бульвар, 29, м. Одеса, Україна, 65044

E-mail:khumarova@nas.gov.ua

\section{ПРІОРИТЕТИ СТРАТЕГІЧНОГО РОЗВИТКУ ТУРИСТИЧНОЇ ДІЯЛЬНОСТІ В КРАЇНАХ ЧОРНОМОРСЬКОГО РЕГІОНУ}

У статті обтрунтовано стратегічні напрямки об'єднаної стратегії краӥн Чорноморського басейну зі створення сприятливих умов формування $і$ розвитку сучасної конкурентоспроможної рекреаційно-туристичної індустрії, здатної стати провідним сектором сталого розвитку цьього регіону. Визначено відповідні иільові установки, пріоритети та завдання. Проаналізовано існуючі недоліки, які знижують конкурентоспроможність туристичних продуктів і послуг в країнах Чорноморського басейну.

Ключові слова: об'єднана стратегія, краӥни Чорноморського басейну, умови розвитку конкурентоспроможної рекреаційно-туристичної індустрї, ичілі і завдання рекреаційно-туристичної діяльності, екологізація туристичної сфери, інновачійний потенціал. 
Formulation of the problem. Modern international tourism is a dynamically developing global subsystem of the world economy. The main objectives of international tourist arrivals during recent years are: Leisure and travel (more than 50\%), business and professional - 15\%, visiting relatives, pilgrimage, etc. - $27 \%$. The global trend is the predominant use for air travel (53\%), as well as flights to exotic countries. Under the influence of the increasingly complex structure of tourist demand, the segmentation of the world tourist market and the diversification of the tourist offer addressed to specialized (target) consumers. New directions of tourism and recreation have emerged and are actively developing - ecological, extreme, rural, etc. There is a transformation of recreational activities, classical balneo-muddy resorts expand recreational functions, priority is given to SPA-therapy, short-term intensive wellness programs and "beauty tours". Regular growth in the world market of tourist services is the growth of competition, which is explained by the active implementation by developed countries and transnational companies of their strategic plans for tourist expansion, as well as significant saturation of the widely developed market sectors (for example, the beach holiday market). In the context of this, there is a need to justify scientific approaches to developing a strategy of the unifying efforts of the countries of the Black Sea basin in the direction of advancing their tourist potential, the integrated use of natural resource capital and increasing the attractiveness of this region for a wider range of consumers.

Analysis of publications. Theoretical, methodological and applied fundamentals of strategic planning and forecasting of recreational and tourist activities, taking into account its significant contribution to the socioeconomic development of the national economy, are considered in the works of domestic scientists N. Andreeva, Gerasimenko, P. Gudzya, V. Evdokimenko, N. Kolendy, V. Kravtsova, A. Martienko, S. Nezdeyminova, L. Cherchik, A. Shevchenko and many others [1,2,3,4,5]. Strategic directions for the development of recreational and tourist activities are explored both from the standpoint of implementing state and regional priorities, and taking into account the trends of the international market. At the same time, the issues of the strategic vector of development of the national recreational and tourist sphere in the context of interregional cooperation and cooperation remain insufficiently studied, including those concerning the identification of tasks for coordinating the actions of the countries of the Black Sea region.

The purpose of the article is substantiation of strategic directions of the joint policy of the countries of the Black Sea basin to create favorable conditions for the formation and development of a modern competitive recreational and tourism industry that can become the leading sector of sustainable development in the region, and also set the appropriate targets, priorities and tasks.

Statement of the main material. In the world market, the competitiveness of an individual country is most often provided by such factors as state policy and legislation in the sphere of tourism; National and international security; sanitary condition and the level of health care; Degree of development of the infrastructure of air, water and land transport; Hotel and restaurant infrastructure; Availability of means of communication; Conformity of price offers; The attitude of the local population to tourists; A variety of natural and cultural resources, etc.

A significant interest in modern recreational and tourist activities is associated with the provision of environmental standards and environmental protection. The need for ecologization of this sphere is determined by a sharp deterioration in the quality of the recreation environment, caused by the growing impact of adverse natural and anthropogenic processes. At the same time, tourism itself has a significant impact on nature and in the future the degree of impact will increase, which is caused by the growth of welfare, a change in lifestyle and demographic changes in the population. Already in many popular areas of tourists the maximum level of stability of natural complexes is exceeded and deep, irreversible changes occur. Thus, the natural resource factor that ensures the attractiveness and competitiveness of the region continues to play an important role in the distribution of international tourist traffic.

It should also be noted that the quality of the national recreational and tourism product is significantly influenced by the development of new forms of entrepreneurial activity in this area. The modern competitive advantages of the subjects of the tourism market include such:

- Presence of a certain innovative potential, including highly professional staff with creative thinking;

- The success of applying innovation as a resource for differentiating tourist products and wider coverage of the consumer market, optimizing the cost of services and creating new markets that provide an exclusive position; 
- Demonstration of readiness for perception and application of best practices, incl. By participating in international research programs, projects, etc .;

- Conducting monitoring studies of the international market, a clear response to changes in the tourist situation and readiness for organizational innovations (including international associations and various forms of cooperation).

Analysis of modern initiatives of international tourism organizations, as well as national and regional strategies for the development of tourism, shows that principles are formulated to ensure sustainable (balanced) development, the implementation of which will reduce the material, energy, water consumption of a tourist product and preserve the quality of the environment. To date, various widely recognized environmental marking procedures for tourism have been developed, international systems and standards for environmental safety and environmental quality management. In connection with the increase in the level of urbanization in many countries (including both the increase in the urban population and the spread of urban lifestyles), forms tourist preferences for recreation and recreation in the natural environment, incl. short-term in urban recreational areas, and in rural areas.

World tendencies on development of new territories testify to the prospect of activization of traditional types of tourism, incl. natural-cognitive, ecological, rural, sports and extreme tourism in remote, inaccessible and less well-known territories.

The development of the tourist activities of the Black Sea countries in particular: Greece, Turkey, Bulgaria, Georgia, Ukraine, Armenia, the Republic of Moldova is also influenced by the intensification of the processes of globalization, ecologization, transition to an information society, the dynamism of crisis phenomena in the world economy and the growth of competition on the international market of tourist services. In these conditions, there is a need to define a new vector of strategic development of tourism in the countries of the Black Sea region and to find ways of its active integration into the system of the world tourist movement.

The starting point of the strategic planning of recreational and tourist activities is a comprehensive assessment of the natural and resource potential of the countries of the Black Sea region, including a retrospective and actual analysis of internal and external factors of both initiatory and deterrent activities. The study of the components of the economic potential of the territories includes an analysis of economic relations and institutions that indirectly affect the reproductive potential [7].

Accordingly, the joint strategy of the countries of the Black Sea basin to create favorable conditions for the formation and development of a modern competitive recreation and tourism industry should be based on clearly identified goals, priorities and tasks for the future development of this area in the region. To do this, it is necessary to determine the strategic directions and priorities of the interested Black Sea countries to create conditions for the creation of a modern competitive tourism industry that can become the leading sector of sustainable development of the Black Sea region.

The assessment of the general state of the institutional and production sphere of recreational and tourist activities in the countries of the Black Sea region shows that this sphere of economic activity has a significant impact on their economies, providing jobs to local people, maintaining balance of payments stability and stimulating the growth of the national gross domestic product of each country.

At the same time, the share of tourism activities of these countries in the tourism industry of the world economy is insufficient. Indicative in this case is the competitiveness rating of travel and tourism, published by the World Economic Forum (WEF), where the countries of the Black Sea occupy respectively such places.

Ukraine in 2015 was not included in the rating "because of insufficient data" [8].

The rating of the WEF was formed taking into account 14 key parameters that take into account: cultural resources, the availability of infrastructure, the price of tourism products, the level of security, international openness, etc.. As can be seen from the table for the period 2013-2015. Only Greece, Turkey and Bulgaria managed to improve their rating by one or two positions. At the same time, they reduced their rating from 5 to 10 positions Georgia, Armenia, Moldova. Ukraine was not included in the rating of the competitiveness of travel and tourism in 2015 due to changes in the management structure and the transfer of the Department of Tourism from the Ministry of Infrastructure of Ukraine to the structure of the Ministry of Economic Development and Trade of Ukraine, which prevented timely provision of the necessary data on indicators of the state of tourism in our countryThe rating indicators of the competitiveness of the national recreation and tourism sector can be 
improved by developing their overall strategy in the sphere of tourism of the countries of the Black Sea basin and cooperating in joint efforts.

\begin{tabular}{|l|l|l|l|l|}
\hline \multirow{2}{*}{ Country } & \multicolumn{2}{|l|}{ Rating } & \multicolumn{2}{l|}{$\begin{array}{l}\text { Index } \\
\text { Competitiveness }\end{array}$} \\
\cline { 2 - 5 } & 2013 year & 2015 year & 2013 year & 2015 year \\
\hline Greece & 32 & 31 & 4,75 & 4,4 \\
\hline Turkey & 46 & 44 & 4,44 & 4,1 \\
\hline Bulgaria & 50 & 49 & 4,3 & 4,0 \\
\hline Georgia & 66 & 71 & 4,1 & 3,7 \\
\hline Ukraine & 76 & $*$ & 3,98 & - \\
\hline Armenia & 79 & 89 & 3,96 & 3,4 \\
\hline $\begin{array}{l}\text { Republic of } \\
\text { Moldova }\end{array}$ & 102 & 111 & 3,6 & 3,2 \\
\hline
\end{tabular}

At the present stage of development of tourism activities in the countries of the group under study, there are certain shortcomings that reduce the competitiveness of their tourism products and services, the main ones being:

- The lack of a single information base that ensures the interaction of travel agencies, associations and centers between the states of the Black Sea basin;

- Ineffective activities to identify and promote the brand of the Black Sea region, which reduces the image of the region in the global tourism market;

- The absence of common tourist routes that unite the states of the Black Sea basin for various types of tourism based on common natural and cultural values;

- Insufficient level of development of the unifying (integral) tourist and recreational infrastructure and its unsatisfactory condition (except for Greece, Turkey and partly Bulgaria);

- Inconsistency of the development level of the tourism industry with the existing natural and recreational potential of the Black Sea region and the absence in the region of international tourist clusters.

Based on the study of the main areas of tourism, the material and natural resource potential of the Black Sea region available in the countries, the following conclusions and suggestions can be made regarding the purpose and prospects of the Black Sea region for the near future. First of all, this is:

- A region with a developing tourism industry, striving to ensure year-round employment and improve the standard of living of the population;

- A region of international specialization with mud-bath resorts, centers of family and children's seaside holidays, areas of rural, sports and extreme tourism, centers of excursion, business, ethnographic and festival tourism;

- Region with steady but uneven tourist flows;

- Region with the priorities of systematic introduction of food, technological and managerial innovations into the tourism industry and ensuring high standards of quality of basic and additional services;

- A region with an optimal economic infrastructure that provides for conflict-free, conjugate development of all spheres of the tourism industry and the economy as a whole;

- A region with a diverse and rich natural environment, and a desire for sustainable use of natural resources.

To ensure the desired results, in our opinion, one of the primary strategic goals and objectives is:

Goal I. Creation of a unified information base ensuring effective interaction of travel agencies, associations and centers of the Black Sea basin states on the basis of the maximum simplicity and accessibility of the use of integrated information on tourist resources and services of the Black Sea countries.

To achieve this goal, it is necessary to solve the following tasks: 
- Provide consumers of tourism resources and services with quality information about all types of tourism activities in the region;

- Create an Internet forum "Tourism and recreation on the shores of the legendary Black Sea".

Goal II. Optimization of the functional structure of the tourism activities of the Black Sea basin states for maximum diversification of the structure of tourism activities and promotion of the brand (image) of the Black Sea region.

To achieve this goal contributes to the following tasks:

- Promotion of traditional and support of new sectors of tourism on the principles of sustainable development, development of rich (unclaimed) natural and resource potential, as well as the creation of new tourism products, taking into account the trends in demand in the global tourism market;

- Infrastructure support for the diversification of tourism activities, the integrated development of a variety of types and forms of tourism and recreation, tied to the existing accommodation base and providing year-round maintenance of tourists and holidaymakers.

To date, the primary objectives of the joint strategy of the countries of the Black Sea basin to create favorable conditions for the formation and development of a modern competitive recreational and tourism industry are:

- Formulate a strategic vision (priorities) of the Black Sea countries' tourist activities for the future and define the mission of the Black Sea Coast;

- To carry out a comprehensive monitoring of the natural and resource potential of tourism development, the current state and trends in the development of recreational and tourist activities in the region;

- Identify problematic issues for the development of tourism activities in the region;

- To assess the competitive advantages and limiting factors of the development of various types of recreational and tourist activities in the region;

- To determine the strategic goals and objectives of the development of recreational and tourist activities in the context of each interested country of the Black Sea region;

- To develop the basic organizational and economic mechanisms for implementing this Strategy.

Conclusions. The development of a joint strategy of the Black Sea basin countries to create favorable conditions for the formation and development of a modern competitive recreational and tourism industry will help coordinate the efforts of the countries concerned and achieve good results in the realization of the cultural, economic and environmental advantages of the recreational and tourist sphere in the Black Sea countriesAllows to determine the prospects and develop specific proposals for the development of tourism activities based on new innovative solutions.

\section{REFERENCES}

1. Herasymenko, V. H. Bedradina, H. K., Halasiuk, S. S. etc. (2016). Otsinka turystychno-rekreatsiinoho potentsialu rehionu. Odesa : ONEU.

2. Hudz M. V. (2010). Potentsial prymorskoi kurortno-rekreatsiinoi terytorii: stan i perspektyvy vykorystannia. Donetsk: Yuho-Vostok.

3. Nezdoiminov, S. H. (2010). Napriamy i formy rozvytku rekreatsii ta turyzmu v rehioni na zasadakh aktyvizatsii pidpryiemnytskoi diialnosti: doctoral thesis. Odesa: In-t probl. rynku ta ekon.-ekol. doslidzh. - .

4. Burkynskyi B.V., Martiienko A.I., Khumarova N.I. (2017). Instytutsiini zasady udoskonalennia vidnosyn vlasnosti na rekreatsiino-turystychni resursy v Ukraini [Institutional framework of improving ownership relations of recreation and tourism resources in Ukraine]. Ekonomika Ukrainy - Economy of Ukraine. 2, 61-74.

5. Cherchyk, L.M., Mostenets, O.V. (2016). Mekhanizm zabezpechennia konkurentospromozhnosti rekreatsiinoi systemy rehionu. Lutsk: Vezha-Druk.

6. Yizha M. M. etc. (2016). Rehionalnyi turystychnyi produkt: proektnyi pidkhid do zabezpechennia konkurentospromozhnosti. Odesa : ORIDU NADU.

7. Khumarova N.I. (2011). Ekolohooriientovane stratehichne planuvannia rozvytku terytorii. Odesa : In-t probl. rynku ta ekon.-ekol. doslidzh. NAN Ukrainy.

8. Ukrayna v 2015 hodu ne voshla v reitynh "yz-za nedostatochnoho kolychestva dannykh". Analytycheskyi portal «Delo.ua». Retrieved from: http://delo.ua/lifestyle/ispanija-vozglavila-rejtingkonkurentosposobnosti-v-sfere-turizm-296190 